\title{
Legume-cereal forage mixtures for silage 2. Nutritive value of silage for dairy cows
}

\author{
A. Urbański ${ }^{1}$ and F. Brzóska ${ }^{2}$ \\ Research Institute of Animal Production \\ 'Experimental Farm, Lipowa \\ ${ }^{2}$ Department of Feed Science and Animal Products \\ 32-083 Balice, Poland
}

(Received 17 July 1995; accepted 12 April 1996)

\begin{abstract}
The nutritive value of silages prepared from mixtures of pea cut at different stages of vegetation (setting of pods, flat pods and full pods with milk and dough maturity of seeds) with spring wheat and Italian ryegrass were similar to that of silages from maize. Dry matter content in silages from the forage mixtures averaged about $19 \%$, whereas from maize about $18 \%$. Mctabolizable energy was 10 and $9.7 \mathrm{MJ} / \mathrm{kg} \mathrm{DM}$, respectively. Voluntary intake of mixture with pea harvested at stage of full pod was similar to that of maize silage being 51.9 and $51.8 \mathrm{k} / \mathrm{kg}^{0.75}$ body weight, respectively. Milk production by cows between 70 and 150 days of lactation, protein and fat content in milk and physical properties of the milk did not differ regardless of type of silage fed.
\end{abstract}

KEY WORDS: pea, spring wheat, Italian ryegrass, silage, nutritive value, cows

\section{INTRODUCTION}

Growth of legume-cereal mixtures with companion crop of Italian ryegrass or lucerne can, because of yield, be an alternative for maize in regions where the growth of the latter is risky or in regions with excessive participation of cereals in crop structure (Brundage et al., 1979; Urbański and Brzóska, 1991; Ostrowski and Daczewska, 1993).

It has been shown that variety of pea and mixture sowing density do not significantly affect the nutritive value of the forage as well as its chemical composition and rumen degradability (Urbański and Brzóska, 1996a). Moreover, no significant effect of variety on nutritive value of forage from pure cultures 
of pea grown for silage in the soil and climatic conditions of Scotland was found (Potts, 1980, 1982). Dry matter yield and nutritive value of the mixtures and of pure cultures of pea depend above all on maturity and growth season, determined by amount and distribution of rainfall and temperature of the air (Potts, 1982; Åman P., Graham H., 1987; Urbański and Brzóska, 1996a). In considering the possibility of growing mixtures of pea and spring cereals for silage, we have undertaken studies to evaluate the chemical composition and nutritive value of silages made from mixtures cut at three stages of pea maturity and to evaluate the productivity of cows receiving diets with these silages.

\section{MATERIAL AND METHODS}

\section{Growth and ensiling of the forage mixtures}

A mixture of pea (var. Koral), spring wheat (var. Henika) and Italian ryegrass (var. Gaza) was shown on 2.5 ha of mineral podsolic soil with $\mathrm{pH}$ 6.5. The forecrop in the mixtures was spring wheat. Sowing was preceded by fertilization with $60 \mathrm{~kg} \mathrm{~N}, 90 \mathrm{~kg} \mathrm{~K}_{2} \mathrm{O}$ and $150 \mathrm{~kg} \mathrm{P}_{2} \mathrm{O}_{5}$ per ha. The individual components of the mixtures were sown at 200,75 or $45 \mathrm{~kg} \mathrm{ha}^{-1}$. Pea and wheat seeds were cross sown with cereal seeder with rows $15 \mathrm{~cm}$ apart. Grass was sown by broadcast sowing and the field then harrowed. No mechanical or chemical weed control of the mixtures was employed. The neighboring field was sown with maize (hybrid Pinto) with 14 thousand plants per ha, $70 \mathrm{~cm}$ apart. The forecrop in this case was spring wheat too. Sowing was preceded by mineral fertilization in amount of $125 \mathrm{~kg} \mathrm{~N}, 100 \mathrm{~kg} \mathrm{P}_{2} \mathrm{O}_{5}$ and $130 \mathrm{~kg} \mathrm{~K}_{2} \mathrm{O}$ per ha and followed by chemical spraying with herbicide. The forage mixture was cut and silaged at three different stages of pea maturity: setting of pods (A), flat pods (B) and full pods with milk and dough maturity of the seeds (C). The mixtures were cut between July 8 and 28. At each stage the forage was collected from $0.8 \mathrm{ha}$. Maize was harvested and ensiled at the milk and dough stage of the grain in the second decade of September. Cutting and harvesting of the mixtures and maize was with Fortschritt E 281C chaff-cutter. Forage was ensiled in the amount of 28 tons for each date, in clamp silos covered with ensiled foil. The silos were opened at the end of November when samples of the silages were taken for chemical analysis and feeding experiments begun.

\section{Animals and feeding}

Digestibility of nutrients of the silages was determined on 16 wethers of highland type with average body weight $55 \pm 4.5 \mathrm{~kg}$, divided randomly into 
4 groups of 4 animals kept in balance cages. The preliminary period of the experiment lasted 21 days, the collection period 7 days. Silages were fed ad libitum with two equal doses during the day, at 7 and $15 \mathrm{~h}$, supplemented with $26 \mathrm{~g} /$ animal/day of Polfamix-vitamin and mineral mixture. The animals received water ad libitum twice daily after feeding. Dry matter in silage, feed intake, refusals and faeces voided are determined daily. Ten percent of daily faeces was taken and frozen. After the end of the experiment the samples were pooled, homogenized and representative samples removed for chemical analysis.

A 24 days feeding experiment on cows using the Latin double square system (4 rations, 4 periods, 2 squares) was conducted in which the studied silages were compared with maize silage. Red-and-White Lowland cows with average body weight $658 \pm 37 \mathrm{~kg}$ were chosen from a herd of 120 cows according to the age, lactation (between day 70 and 150), date of calving, body weight and current productivity and were fed according to Polish standards (Ryś, 1982). Rations for cows contained silage from forage mixtures corresponding to stages of pea maturity (groups I, II and III) and maize silage (group IV). The amounts fed were about $3.70 \mathrm{~kg} \mathrm{DM} /$ day and silage from wilted meadow and pasture herbage fed in amount of $4.5 \mathrm{~kg} \mathrm{DM} /$ day. The rations also contained ground barley and MMB mineral mixture fed in the amount of $4.5 \mathrm{~kg} / \mathrm{cow}$ at the beginning and $1.8 \mathrm{~kg} / \mathrm{cow}$ towards the end of the experiment. The amount of silage dry matter intake was determined daily. During the last three days of each experimental period the yield of milk as well as chemical and physical properties of milk from morning and afternoon milking were estimated. The cows were weighed before feeding on the first day of every period.

\section{Analysis}

Analysis of the silages were carried out as described in the first part of this study (Urbański and Brzóska, 1996a). Content of nutrients in the silages, refusals and faeces was determined by conventional methods (AOAC, 1990) with the use of equipment manufactured by Buchi and Tecator. NDF and ADF were determined according to Goering and Van Soest (1970). Calcium, magnesium, sodium and potassium in the silages was determined by absorption spectroscopy (Philips PU 9400, Pinta, 1977) and phosphorus by the vanadium-molybdenum method (IUNG, 1972). Samples were mineralized in a mixture of nitric and perchloric acids (Pinta, 1977). Nitrogen content in faeces was determined in thawed homogenized samples. Gross energy content in the silages was calculated from crude nutrients content and that of digestible and metabolizable energy from digestible nutrients according to Schiemann et al. (1971) and from coefficients of energy utilization according to Van Es (1975). Fat content in the milk was assayed with Mk-III Milko tester and crude protein with Mk-II Pro 
milk (Foss-electric). Density, acidity and coagulation time of milk was determined according to the Polish standard (PN 68/A-86122). FCM and daily production of fat and protein in milk was calculated.

The data obtained were subjected to variance analysis and Tuceys test (Elandt, 1964).

\section{RESULTS}

\section{Chemical composition of silages}

The quality of silages from legume-cereal mixtures and from maize silage estimated organoleptically was very good. Dry matter content in the silages ranged from 171.4 to $212.5 \mathrm{~kg}^{-1}$ of feed. $\mathrm{pH}$ values ranged from 3.9 to 4.1 (Table 1). Silages from the mixtures had an olive green color, pleasant smell and well preserved plant structure. The degree of protein degradation to ammonia in silages from the mixtures was higher than in maize silage but did not exceed $9 \%$ $\mathrm{NH}_{3}-\mathrm{N}$ in total-N. The content of protein and monosaccharides in the studied silages was higher than in maize silage whereas that of fibre and remaining structural carbohydrates was similar. Delayed harvest of the forage mixtures was accompanied by reduced protein and sugar content and increased content of structural carbohydrates in the silages. The content of calcium, magnesium, sodium and potassium in silages from the mixtures was by $10-20 \%$ higher than in those from maize (Table 2).

TABLE 1

Characteristics of silages

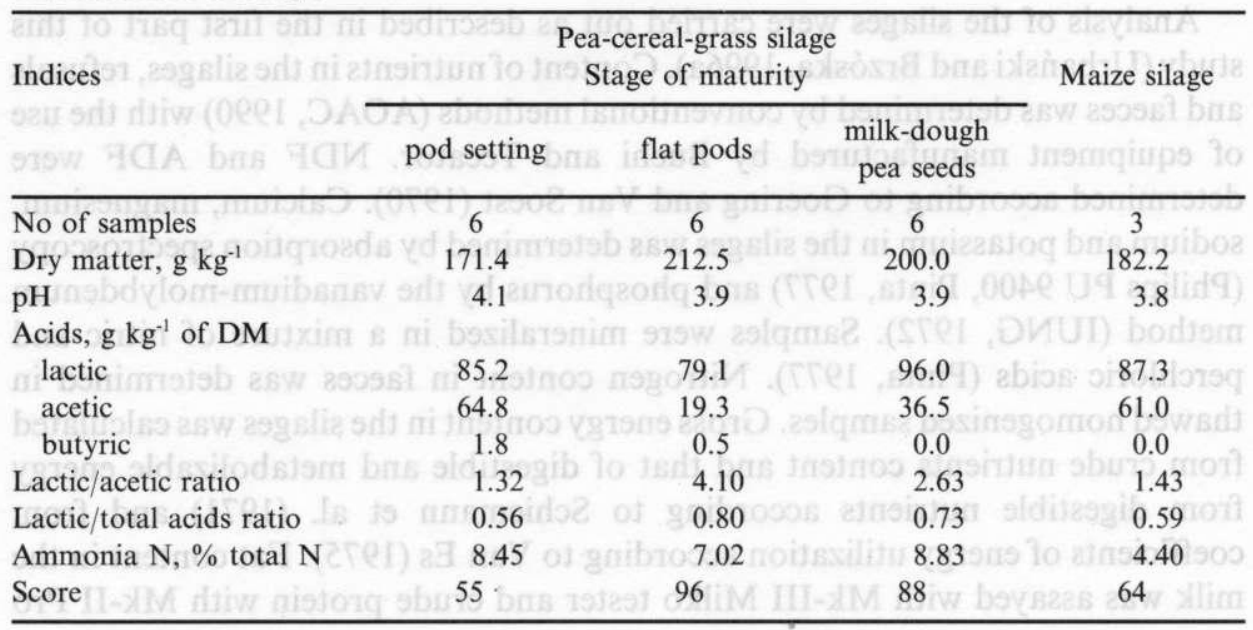


TABLE 2

Chemical composition of silages

\begin{tabular}{|c|c|c|c|c|}
\hline \multirow[t]{3}{*}{ Indices } & \multicolumn{3}{|c|}{$\begin{array}{l}\text { Pea-cereal-grass silage } \\
\text { Stage of maturity }\end{array}$} & \multirow[t]{2}{*}{ Maize silage } \\
\hline & pod setting & flat pods & $\begin{array}{l}\text { milk-dough } \\
\text { pea seeds }\end{array}$ & \\
\hline & \multicolumn{4}{|c|}{ Organic nutrients, $\mathrm{g} \mathrm{kg}^{-1}$ of $\mathrm{DM}$} \\
\hline Organic matter & 913.0 & 929.0 & 910.7 & 924.7 \\
\hline Crude protein & 130.3 & 122.4 & 114.6 & 110.8 \\
\hline Ether extract & 63.3 & 42.2 & 51.4 & 35.5 \\
\hline Crude fibre & 307.1 & 323.2 & 320.2 & 324.5 \\
\hline NDF & 546.7 & 575.4 & 573.0 & 654.3 \\
\hline $\mathrm{ADF}$ & 336.1 & 361.8 & 354.5 & 353.3 \\
\hline ADL & 50.2 & 52.1 & 46.3 & 64.3 \\
\hline $\mathrm{N}$-free extractives & 412.3 & 441.2 & 414.5 & 454.9 \\
\hline \multirow[t]{2}{*}{ Water soluble carbohydrates } & 77.7 & 69.8 & 66.9 & 63.8 \\
\hline & \multicolumn{4}{|c|}{ Mineral nutrients, $\mathrm{g} \mathrm{kg}^{-1}$ of $\mathrm{DM}$} \\
\hline Ash & 87.0 & 71.0 & 89.3 & 75.3 \\
\hline Calcium & 9.2 & 9.0 & 8.3 & 7.5 \\
\hline Phosphorus & 3.4 & 3.2 & 3.5 & 2.9 \\
\hline Magnesium & 2.0 & 1.8 & 1.9 & 1.2 \\
\hline Sodium & 1.2 & 1.3 & 1.3 & 1.1 \\
\hline Potasium & 40.2 & 32.6 & 34.3 & 27.7 \\
\hline
\end{tabular}

Voluntary intake, digestibility and nutritive value of the silages

Voluntary intake of organic matter of silage from the mixtures by sheep was $1032.3 \mathrm{~g}(922.1-11301.1) \mathrm{g} /$ day and did not differ, with the exception of the flat pea pod stage $(\mathrm{P} \leqslant 0.01)$, from the intake of maize silage. The intake of organic matter of silage from the mixtures per $1 \mathrm{~kg}$ metabolic body weight was 51.3 (46.1-55.9) $\mathrm{g} /$ day and for maize $51.8 \mathrm{~g} /$ day. There were no statistically significant differences in the digestibility of the nutrients in silages from mixtures and from maize $(P \geqslant 0.010)$. The energy value of silages from the mixtures averaged 18.68 $\mathrm{MJ}$ gross energy, 12.38 $\mathrm{MJ}$ digestible energy and $10.14 \mathrm{MJ}$ metabolizable energy kg-1 $\mathrm{DM}$ whereas the corresponding values for maize silage were: $18.49,11.99$ and $9.66 \mathrm{MJ} \mathrm{kg}^{-1} \mathrm{DM}$. Maturation of pea was accompanied by reduced values of organic matter digestibility, NDF and ADP as well as energy value of the silages. However, the differences were not significant $(P \geqslant 0.01$; Table 3). 
Silage voluntary intake and nutrients digestibility

\begin{tabular}{|c|c|c|c|c|c|}
\hline \multirow[t]{2}{*}{ Indices } & \multicolumn{3}{|c|}{$\begin{array}{l}\text { Pea-cereal-grass silage } \\
\text { Stage of maturity }\end{array}$} & \multirow[t]{2}{*}{$\begin{array}{l}\text { Maize } \\
\text { silage }\end{array}$} & \multirow[t]{2}{*}{$\mathrm{SEM} \pm$} \\
\hline & pod setting & flat pods & $\begin{array}{l}\text { milk-dough } \\
\text { pea seeds }\end{array}$ & & \\
\hline \multicolumn{6}{|l|}{ Intake } \\
\hline Dry matter, g/day & $1010.0 \mathrm{~b}$ & $1216.5 \mathrm{a}$ & $1147.0 \mathrm{a}$ & $1128.2 \mathrm{ab}$ & 21.9 \\
\hline Organic matter, g/day & $922.1 \mathrm{~b}$ & $1130.1 \mathrm{a}$ & $1044.6 \mathrm{a}$ & $1043.5 \mathrm{a}$ & 21.5 \\
\hline Organic matter, g/day ${ }^{0.75} \mathrm{BW}$ & 46.1c & $55.9 \mathrm{a}$ & $51.9 \mathrm{~b}$ & $51.8 \mathrm{~b}$ & 1.4 \\
\hline \multicolumn{6}{|c|}{ Apparent digestibility coefficients, $\%$} \\
\hline Dry matter & 69.20 & 67.69 & 65.40 & 66.21 & 0.83 \\
\hline Organic matter & 71.16 & 69.39 & 68.10 & 67.79 & 0.76 \\
\hline Crude protein & 66.26 & 67.61 & 58.95 & 60.48 & 1.54 \\
\hline Ether extract & 74.82 & 69.27 & 69.79 & 70.52 & 1.03 \\
\hline Crude fibre & 67.32 & 63.48 & 67.54 & 69.83 & 1.05 \\
\hline N-free extractives & 75.00 & 74.22 & 72.81 & 67.90 & 0.99 \\
\hline NDF & 61.71 & 58.49 & 57.89 & 64.37 & 1.18 \\
\hline $\mathrm{ADF}$ & 60.12 & 59.88 & 56.26 & 62.45 & 1.14 \\
\hline \multicolumn{6}{|l|}{ Nutritive value, $\mathrm{MJ} / \mathrm{kg}$ of $\mathrm{DM}$} \\
\hline Gross energy & 18.89 & 18.75 & 18.39 & 18.49 & \\
\hline Digestible energy & 12.78 & 12.36 & 11.99 & 11.99 & \\
\hline Metabolizable energy & 10.54 & 10.05 & 9.83 & 9.66 & \\
\hline
\end{tabular}

$a, b, c-$ values in the rows with differ letters are differ significantly $(P \leqslant 0.01)$

\section{Productivity of cows and characteristics of milk}

The intake of silages from the mixtures and maize silage was similar and averaged $3.75 \mathrm{~kg} /$ day for the mixtures and $3.69 \mathrm{~kg} /$ day for maize. Intake of feed dry matter by cows was 10.27 and $10.04 \mathrm{~kg} /$ day, respectively. The milk output (FCM) of cows receiving silage from the mixtures throughout the experiment averaged $16.1 \mathrm{~kg}$ and for those receiving maize silage $16.6 \mathrm{~kg} /$ day $(P \geqslant 0.01)$. The differences in FCM, composition and characteristics of milk from cows receiving rations containing the separate silages, as well as differences in body weight of cows fed silages from the mixtures and from maize were not significant $(P \geqslant 0.05)$.

\section{DISCUSSION}

The results of our earlier studies (Urbański and Brzóska, 1991, 1996a) showed that cultivation of forage mixtures of pea with spring wheat and Italian ryegrass in highland areas may be an alternative for maize with regard to yield and 
chemical composition of the silages. Changes in dry matter content in the silages in these studies compared to earlier ones may result from different weather conditions during harvest and ensiling of the forage mixtures as well as during the whole growth period of the plants. Dry matter content in silages from maize was also low, this being characteristic for the region due to high air humidity, frequent fogs and rainfall at the end of September and beginning of October. A similary low dry matter content was described for silages from pea grown in pure culture under British conditions (Potts, 1980, 1982). The reaction and level of acids in silages from whole cereals or their mixtures with grasses was similar (Kung et al., 1990; Walker et al., 1990). The studied silages had good physical structure, contained trace amounts of butyric acid and moderate level of ammonia. This indicates the proper course of fermentation. Silages from the forage mixtures had a higher content of protein and mineral components than those from maize but both had a similar content of crude fibre and readily fermentable sugars. The chemical composition of the silages was the most favourable when pea was cut at the stage of flat pods or filled pods with milk and dough maturity of grain. The nutritive value of the silages was similar to the value given by Ostrowski and Daczewska (1993) for silages from pea with spring wheat and lucerne.

Voluntary intake of organic matter of silage from mixtures of pea with wheat and grass was higher than those of silages from whole oat and barley plants in the studies of Bolsen and Bergen (1976) but was similar to the intake of silage from whole cereals described by Mannerkorpi (1990). Intake of silages was similar to the intake of any kind of silage from grasses in our earlier studies (Brzóska et al., 1993) though lower than for silages from forage mixtures (Ostrowski and Daczewska, 1993). Digestibility of organic matter of the silages determined on growing wethers fed ad libitum was relatively high and similar to the digestibility of maize. The concentration of metabolizable energy in studied silages ranged from 9.7 to $10.5 \mathrm{MJ} \mathrm{kg}^{-1} \mathrm{DM}$ and was similar to the energy content in maize silage. The energy value showed a slight drop with maturation of pea, being characteristic for forage plants (except for maize) and results from reduced digestibility of organic matter with increase of NDF and ADF content and lignification of the cell walls of plants.

If the utilization of metabolizable energy of silages for milk production is consistent with the level given by Van Es (1975), the net energy for lactation in silages from the mixtures ranged from 5.72 to $5.39 \mathrm{MJ}$ NEL in first and third stages of pea maturity and 5.27 MJ NEL kg-1 DM of maize silage. The energy value of silages from similar mixtures in two consecutive years in studies by Ostrowski and Daczewska (1993) was 5.81 and 5.50 MJ NEL kg-1 DM.

Our studies indicate that the optimal date for harvest and ensiling of the investigated forage mixtures is the stage of milk and dough maturity of pea seeds. 
TABLE 4

Feed intake, milk yield and composition and body weight of cows

\begin{tabular}{|c|c|c|c|c|c|}
\hline \multirow[t]{2}{*}{ Indices } & \multicolumn{3}{|c|}{$\begin{array}{l}\text { Pea-cereal-grass silage } \\
\text { Stage of maturity }\end{array}$} & \multirow[t]{2}{*}{$\begin{array}{l}\text { Maize } \\
\text { silage }\end{array}$} & \multirow[t]{2}{*}{$\mathrm{SEM} \pm$} \\
\hline & pod setting & flat pods & $\begin{array}{l}\text { milk-dough } \\
\text { pea seeds }\end{array}$ & & \\
\hline \multicolumn{6}{|l|}{ Feed intake, $\mathrm{kg}$ of $\mathrm{DM} /$ day } \\
\hline Pea-cereal-grass silage & 3.80 & 3.77 & 3.69 & - & 0.18 \\
\hline Maize silage & - & - & - & 3.69 & 0.10 \\
\hline Grass silage, $44 \%$ of DM & 4.49 & 4.74 & 4.54 & 4.54 & 0.05 \\
\hline Concentrate* & 1.75 & 1.64 & 1.80 & 1.80 & 0.10 \\
\hline Total & 10.74 & 10.15 & 10.04 & 10.04 & 0.10 \\
\hline \multicolumn{6}{|l|}{ Nutrient intake } \\
\hline Dry matter, g/day & 17.70 & 18.20 & 17.80 & 17.90 & 0.45 \\
\hline Crude protein, g/day & 1845 & 1826 & 1774 & 17.84 & 27.00 \\
\hline NEL, MJ/day & 60.31 & 59.99 & 58.37 & 58.61 & 0.66 \\
\hline \multicolumn{6}{|l|}{ Milk yield, constituents } \\
\hline Milk, kg/day & 17.50 & 17.50 & 17.60 & 18.10 & 0.48 \\
\hline FCM, kg/day & 16.10 & 16.00 & 16.20 & 16.60 & 0.51 \\
\hline Fat, $\%$ & 3.47 & 3.44 & 3.43 & 3.44 & 0.06 \\
\hline Protein, \% & 2.95 & 2.86 & 2.82 & 2.87 & 0.02 \\
\hline Density, ${ }^{0} \mathrm{Ld}$ & 28.30 & 28.00 & 28.30 & 28.50 & 0.13 \\
\hline Acidity, "SH & 7.13 & 7.15 & 7.00 & 7.07 & 0.11 \\
\hline Reneting time, sec. & 146 & 152 & 160 & 163 & 0.31 \\
\hline \multicolumn{6}{|l|}{ Cows body weight, $\mathrm{kg}$} \\
\hline Average & 572.00 & 565.50 & 567.00 & 568.50 & 0.37 \\
\hline Daily changes & -0.22 & -0.07 & -0.16 & -0.03 & - \\
\hline
\end{tabular}

* - barley, ground with mineral supplements all differences between values in rows were not significant $(P \leqslant 0.01)$

Rundgren (1983) and Åman and Graham (1987) basing on analysis of starchy and structural carbohydrates content of pea plants concluded that the best date for harvest and ensiling of pea forage is the stage of filled pods with green vegetative parts of the plants, which corresponds to milk and dough maturity of the seeds. They also demonstrated that at later stages of pea maturity the content of monosaccharides in the forage drops and the content of starchy carbohydrates in the pea seeds increases. These changes may worsen the conditions for lactic fermentation in the silages and therefore reduce the aerobic stability of the silages during feeding.

When the studied silages were used together with grass silage as feed for cows in the first half of lactation the cows produced a similar quantity of milk with similar chemical composition and physical traits as in the case of maize silage. The higher costs of seeds of the mixtures compared to maize are compensated for 
by lower cost of cultivation due to lower use of mineral fertilizers, useless of herbicide and simple sowing technique. For these reasons cultivation of legume-cereal mixtures with grasses for silage can be regarded as ecologically friendly.

\section{CONCLUSIONS}

Silages made from mixtures of pea, spring wheat and Italian ryegrass grown in highland areas at the stages from pod setting to full pea pods with milk and dough maturity of seeds are characterized by higher content of crude protein, calcium, phosphorus and magnesium and similar content of dry matter, metabolizable energy and net energy for lactation compared to silage from maize.

Taking into account the chemical composition, voluntary intake, digestibility and energy value of the silages the best date for harvest and ensiling the mixtures is that of full pods with milk and dough maturity of seeds. The use of silages from mixtures in cow feeding, instead of maize silage in rations together with silage from partly wilted grasses, results in similar production of milk with similar composition and physical properties.

\section{REFERENCES}

Åman P., Graham H., 1987. Whole-crop peas. I. Changes in botanical and chemical composition and rumen in vitro degradability during maturation. Anim. Feed Sci. Technol. 81, 15-31

AOAC, 1990. Official Methods of Analysis of the Association of Official Analytical Chemists. 15th edition, Arlington, Virginia, USA

Bolsen K.K, Bergen L.L. 1976. Effects of type and variety and stage of maturity on feeding value of cereal silage for lambs. J. Anim. Sci. 42, 168-174

Brundage A.L., Raylor R.L., Burton V.L., 1979. Relative yield and nutritive values of barley, oats and peas harvested at four successive dates for forage. J. Dairy Sci. 62, 740-745

Brzóska F., Brejta W., Zyzak W., Brzóska B., Gąsior R., 1993. Effect of grass maturity and prewilting on silage nutritive value, bulls fattening efficiency and carcass quality (in Polish).

Rocz. Nauk. Zoot. 20, 193-211

Elandt R., 1964. Statistics in Experimental Agriculture (in Polish). PWRiL, Warszawa

IUNG, 1972. Laboratory methods in chemical agriculture stations. Part II (in Polish). IUNG Puławy (Editor)

Kung L. Jr, Carmean B.R., Tung R.S., 1990. Microbial inoculation or cellulase enzyme treatment of barley and vetch silage harvested at three maturities. J. Dairy Sci. 73, 1304-1311

Mannerkorpi P., 1990. Ad libitum Futteraufnahme und Verdaulichkeid der Nährstoffe von Ganzphlanzesilage aus Weizen ung Gerste bei Wiederkäuern. Einfluss des Reifegrass und der Schnitthöhe. Dissertation, der Christian-Albrechts-Universität zu Kiel 
Ostrowski R., Daczewska M., 1993. The yield of cereal-legume mixtures under conditions of the Wielkopolska region and nutritive value of silages and dried forage for ruminants (in Polish). Rocz. Nauk. Zoot. 20, 157-169

Pinta M., 1977. Absorption Automatic Spectrometry (in Polish). PWN, Warszawa

Polska Norma (Polish Standard). PN-68/A-86122. Milk. Methods of Investigation (in Polish). Polski Komitet Normalizacji (Polish Committee of Standarization), Warszawa

Potts M.J., 1980. The influence of sowing date, harvest date and seed rate on the yield of forage peas. Grass Forage Sci. 35, 41-45

Potts M.J., 1982. The influence selected agronomic factors on the yield of forage peas. Grass Forage Sci. 37, 327-331

Rundgren M., 1983. Helgrödesensilage av ärter till svin. Swedish University of Agriculture Sciences, Uppsala, Konsulentavdelningens Rapporter Allmänt, 44, 1-9

Ryś. R., 1982. Feeding Standards for Farm Animals (in Polish). PWRiL, Warszawa

Schiemann R., Nehring K., Hoffmann L., Jentsch W., Chudy A., 1971. Energetische Futterbewertung und Energienormen. VEB Dte Landwerl., Berlin

Urbański A., Brzóska F., 1991. Pea-wheat-grass forage yield, nutritive value and silage chemical composition. Proceedings of International Symposium: Forage Preservation, Nitra (Slovakia) pp. 209-213

Urbański A., Brzóska F., 1996a. Legume-cereal forage mixtures for silage. 1. Effect of pea variety, maturity and mixtures sowing density on dry matter yield and silage chemical composition. J. Anim. Feed Sci. 5, 107-116

Van Es A.J.H., 1975. Feed evaluation for dairy cows. Livest. Prod. Sci. 2, 95-107

Walker D.W., West C.P., Bacon R.K., Longer D.E., Turner K.E., 1990. Changes in forage yield and composition of wheat-ryegrass mixtures with maturity. J. Dairy Sci. 73, 1296-1303

\section{STRESZCZENIE}

Mieszanki strączkowo-zbożowe na kiszonkę. 2. Wartość pokarmowa kiszonek w żywieniu krów mlecznych

Wartość pokarmowa kiszonek przygotowanych z mieszanki grochu siewnego, zbieranego w różnych okresach wegetacji (zawiązywania strąków, płaskich strąków i wypełnionych strąków o mleczno-woskowej dojrzalości ziarna), z pszenicą jarą i życicą wielokwiatową była podobna do wartości kiszonki z kukurydzy. Zawartość suchej masy w kiszonkach z mieszanek wynosiła średnio okolo $19 \%$, z kukurydzy $18 \%$, energii metabolicznej odpowiednio około 10 i $9,7 \mathrm{MJ} / \mathrm{kg} \mathrm{SM}$ Dowolne pobranie kiszonki z grochem zebranym w stadium wypełnionego strąka bylo podobne jak kiszonki z kukurydzy i wynosiło odpowiednio 51,9 i $51,8 \mathrm{~g} / \mathrm{kg}^{0.75}$ masy ciała. Produkcja mleka krów między 70 a 150 dniem laktacji, zawartość białka i tłuszczu w mleku oraz właściwości fizyczne mleka nie różniły się w zależności od rodzaju skarmianej kiszonki. 